\title{
DIGITALCOMMONS
}

@WAYNESTATE -

Criticism

Volume 63

Issue 1 The Future(s) of Early Modern Women

Writers (Double Issue)

Article 1

2021

\section{Beyond Canonicity: The Future(s) of Early Modern Women Writers}

Jaime Goodrich

Wayne State University, goodrija@wayne.edu

Paula McQuade

DePaul University, pmcquade@depaul.edu

Follow this and additional works at: https://digitalcommons.wayne.edu/criticism

\section{Recommended Citation}

Goodrich, Jaime and McQuade, Paula (2021) "Beyond Canonicity: The Future(s) of Early Modern Women Writers," Criticism: Vol. 63 : Iss. 1 , Article 1.

Available at: https://digitalcommons.wayne.edu/criticism/vol63/iss1/1 


\title{
BEYOND CANONICITY: THE FUTURE(S) OF EARLY MODERN WOMEN WRITERS
}

\author{
Jaime Goodrich and Paula McQuade
}

This special issue began with a simple question: "What does the future hold for the study of early modern women writers?" The history of this relatively new subfield can be outlined in short order. Its Ur-text is the tale of Judith Shakespeare, a tragic figure invented by Virginia Woolf for $A$ Room of One's Own (1929) in order to explain her inability to locate any talented female writers who were contemporaries of William Shakespeare. Borne on the tide of second-wave feminism, scholars of the 1970s and 1980s found that early modern women did, indeed, write plays, poetry, and romances meriting scholarly attention and critical editions. This germinal work initiated an ongoing process of canon formation that has altered the broader field of early modern literature. Women's writings once circulated DIY-style via ditto machines, mimeographs, and photocopiers. Today, many of these texts are available in mainstream anthologies used in survey courses, specialized readers intended for upper-level English majors and graduate students, and digital editions aimed at academic and general audiences alike. ${ }^{1}$ At the same time, scholars continue to make new discoveries that enrich the canon, most recently by drawing attention to women's use of nonliterary genres such as catechisms, prayers, recipes, and translations. As Margaret J. M. Ezell has noted, the current corpus of women's writings is characterized by its "sparkling multiplicity" rather than "female uniformity," which is evident in even a cursory glance at the pioneering online resources created by the Orlando Project, the Perdita Project, and the Women Writers Project. ${ }^{2}$ Thanks to the efforts of the first generation of scholars, the field now boasts several interdisciplinary initiatives that promote research on early modern women: a triennial conference (Attending to Early Modern Women), a biannual journal (Early Modern Women), a scholarly organization (Society for the Study of Early Modern Women and Gender), and a book series (Women and Gender in the Early Modern World, published by University of Nebraska Press). Respected journals and major university presses frequently publish scholarship on women writers, and papers and 
panels on the topic routinely appear at leading conferences organized by the Renaissance Society of America and the Shakespeare Association of America. Meanwhile, Patricia Pender and Rosalind Smith are currently overseeing The Palgrave Encyclopedia of Early Modern Women's Writing, a digital venture of over 1 million words. ${ }^{3}$ Nearly a hundred years after Woolf, then, this subfield has been established as a viable and vital area of study, one whose depths have yet to be fully plumbed.

Yet despite these advances, early modern women writers have not been fully integrated into the broader field of early modern literature. Because teaching anthologies generally reflect perceptions of the canon at a given moment in time, a historical overview of the Norton Anthology of English Literature provides a rough and ready means of charting the critical reception of early modern women writers. While the first four editions did not incorporate any works by early modern women writers $(1962,1968,1974,1979)$, the fifth edition added texts by six women (1986) and the sixth edition featured the writings of nine women (1993). From the seventh edition (2000) to the tenth (2018), the Norton included selections from fourteen or fifteen early modern women writers, most of which appear as short extracts in thematic sections such as "Women in Power" or "Writing the Self." Over the same period of time, the Norton editors moved toward presenting notable works by early modern men in their entirety, no matter the length. As a result, major female authors are represented by excerpts and major male authors by full texts. The tissue-thin pages of the Norton are famously generous in number, but this lack of parity arguably suggests that early modern women writers have been allotted a token space that cannot be exceeded. The editors' treatment of Elizabeth Cary's Tragedy of Mariam, one of the most important plays by an early modern woman, offers further evidence that female authors have reached a ceiling. Extracts from Mariam appeared in both the seventh and eighth editions of the Norton, but were omitted in subsequent editions in favor of new material by other women writers. Inclusion in the print version of the Norton appears to be a zero-sum game for female authors, as the success of one woman writer comes at the expense of others. Unfortunately, such issues are not limited to the Norton. As several essays in this special issue note, the newly published Routledge Anthology of Early Modern Drama (2020) contains no plays by women even though its predecessor, The Routledge Anthology of Renaissance Drama (2003), included Cary's Mariam. The contents of these mainstream anthologies represent an unspoken but widespread attitude in the field: women's writings are primarily of interest to women, while men's writings are of interest to everyone. 
This perception of women's writing as optional manifests itself in both obvious and subtle ways, from the paucity of male scholars in this subfield to the almost exclusively female audiences who attend conference panels on women writers. Several of the contributors to this special issue mention encountering resistance from their advisors and colleagues as they pursued teaching and research agendas that centered on early modern women writers. Jaime's experiences provide a revealing illustration of the tacit disapproval and discouragement that would-be scholars in this field may encounter. She matriculated at a women's college in 1997, when the Norton contained only nine women writers, and she immediately enrolled in a British literature survey that skewed toward dead, white men, much like the English major itself. In graduate school, her dissertation committee was supportive of her decision to write about gender and translation, but a trusted mentor informed her that gender was not an appropriate category for analyzing literature. Another faculty member observed that she would need to write "something about a man" if she had trouble finding a job. Some of her colleagues at Wayne State also work on women writers, but she has confronted insinuations that her work is boring, traditional, and/or atheoretical—presumably because of its emphasis on methods central to her subfield: historicism, textual criticism, and archival research. Finally, a major university press rejected the proposal for her first book on the grounds that there was no broad readership for the subject of female translators, even though the project devoted substantial space to Elizabeth I, Mary I, and Mary Sidney Herbert, among others. Thus, while the earliest scholars in this subfield took a "Field of Dreams" approach (if we build a canon of women writers, then integration into the canon will come!), we must continue to rebut the idea that women writers are not "important" or "good" enough to merit the kind of attention routinely paid to canonical male authors.

For two decades now, feminist critics have consequently mulledboth in passing and in print-how to make women writers more central to early modern literary studies. An entire genre of essays has arisen on the marginalization of women writers, including a special issue of Women's Writing (2007) on the future of early modern women's writing that resulted from a 2005 conference in honor of the Perdita Project. ${ }^{4}$ Most examples of this "marginalization lit" pursue a triple agenda: 1) to articulate the problem of early modern women's exclusion from the canon; 2) to locate the sources of this problem; 3) to offer one or more solutions. With trenchant precision, scholars have outlined fundamental disparities in the critical reception of women writers. Patricia Phillippy, for example, has observed that "women's writing has been treated as if enacted 
remotely, distinct from masculine practice and canonicity and incommensurate with conventional standards of merit or value." ${ }^{5}$ Meanwhile, Lara Dodds and Michelle M. Dowd commented just last year in the pages of this journal that "the field of early modern women's writing operates as a kind of alternate reality to the wider field of Renaissance literary studies." ${ }^{6}$ In these and other tellings, two narratives explain the existence of this "alternate reality." First, editors have not served female authors well because they failed to represent the diversity of women's writings, ${ }^{7}$ or to generate a distinctively feminist approach suited to the material, ${ }^{8}$ or to produce high-quality editions for a high-street readership. ${ }^{9}$ Second, theoretical trends have prevented the integration of women writers into the canon because of the need to read newly recovered texts through historicism rather than formalism, ${ }^{10}$ or because of the inopportune coincidence of the rediscovery of women writers with the death of the author. ${ }^{11}$ Each essay has recommended practical means of addressing these issues, and scholars have implemented those suggestions by publishing new kinds of editions and by reading women's work through lenses such as feminist formalism. Yet women writers remain isolated from the canon, perhaps because the most basic issues remain unchanged despite our best efforts. For example, the field tends to measure the works of women writers by the Procrustean bed of aesthetic and formal standards established by canonical male authors - and then to marginalize those texts when they do not fit these predetermined criteria.

Like Eliot's Prufrock, then, we have found ourselves trapped in a nightmarish situation where we ask the same questions over and over again, to no end. What is the best vehicle for raising awareness of female authors: the popular edition, the teaching anthology, or the complete scholarly works? Should we model integration by analyzing women writers alongside canonical male authors, or should we adopt a separatist paradigm by reading women writers through feminist critical lenses that generate fresh insights for the field of early modern literature at large? Would removing the words "women" and "gender" from the titles of conference panels, articles, or books ensure a more diverse audience? And as in the case of Prufrock, so far these questions have been futile. To borrow a conceit from Eliot's poem, women writers have not succeeded in becoming central characters - like "Prince Hamlet"-within the dramatic arc of the early modern canon but remain "attendant" ladies who can "swell a progress, start a scene or two." Within the critical framework established by "marginalization lit," early modern women writers are ladies in waiting, who wait patiently for their time to come, for entrance into the (male) canon, for attention outside of their subfield. 
This situation came to a head in 2019, when Diane Purkiss published a review essay for the Times Literary Supplement (TLS) that covered four recent books on early modern women writers. Entitled "Rooms of All Our Own" in an overt nod to Woolf, this piece is a paradigmatic example of "marginalization lit" that hits many familiar notes: the repeated labors of feminist scholars to integrate women writers into the canon, the partial success of these efforts as witnessed by the Norton, and the enduring critical disjunction between the study of early modern women writers and canonical literature. As Purkiss incisively notes, "Women writers of the early modern period have been introduced, and reintroduced, and introduced again, as if the mainstream early modernists were deaf, or very forgetful, elderly uncles. The diligent specialists in early modern women's writing keep finding new ways to frame their introductions in the hope that this time something might stick." 12 Yet instead of castigating the "elderly uncles" who guard the canon, this review marks an unusual turn in the genre of "marginalization lit" by cataloging the failings of feminist scholars. Its main target is A History of Early Modern Women's Writing (2018), a volume edited by Patricia Phillippy (full disclosure: both of us contributed essays to this project). Much more than a simple history, this edited collection provides a complex overview of the state of the field, both in terms of content as well as methodologies. In Purkiss's view, the essays also display the field's weaknesses, including an essentialist conflation of women's experiences, an emphasis on gendered identity politics over other issues, a tendency to view women in isolation from their cultural context, and a universal desire to publish scholarship that does not ruffle any critical feathers. The coup de grâce occurs in these concluding sentences on Phillippy's collection, which are worth quoting at length:

Women scholars are not the ones to blame for [women writers' exclusion from the canon]. They daren't raise their voices. A collection of essays often best expresses the state of play in a scholarly area; this collection, for one, provides polite, scholarly intersections between women who have made a tacit deal with their male colleagues: you get to ignore us in exchange for giving us a small space of our own to work in. A very small space, indeed, since in neither collection reviewed here are contributors postholders from top-ranking universities.

Although Purkiss states outright that "women scholars are not . . . to blame," this passage nonetheless implicitly places at least part of the 
"blame" on these scholars by drawing attention to their agency ("women who have made a tacit deal with their male colleagues"). The current state of affairs is thus attributable not to systemic inequalities but to female critics who have settled for too little and contented themselves with "a small space of [their] own" located outside of "top-ranking universities" rather than holding out for full integration within the canon and positions at Oxbridge-caliber institutions.

This analysis of the situation deserves further scrutiny, particularly in terms of its class and economic aspects. As Diana Henderson has noted in relation to quarrels among feminist scholars, such internecine attacks only divert our focus from the structural inequities that sustain patriarchal oppression:

turning our criticism on one another . . . often signal[s] obliviousness to the larger political landscape in which we are participating whether we like it or not. If there is a zero-sum game involved, it is surely not at the disciplinary or subfield level but at a much higher level of administrative decision-making, which is where economic arguments should be aimed. Simply put, misrecognizing the problem as an "us versus us" debate (as in much of our scholarship) rather than an "us versus them" restructuring, wherein we need to be united and "they" are much larger and uninterested in our academic debates, will not serve any of us well. ${ }^{13}$

Purkiss's caustic aside about the collection's lack of female scholars at elite universities thus misses the larger structural issues in play. Although tenured professorships at well-funded universities certainly make it easier to do field-changing work, top-notch scholarship can occur anywhere. To cite just one example, the late Margaret Hannay spent her career at a small liberal arts college with a religious affiliation, where she produced foundational and widely acclaimed work on Mary Sidney Herbert and Mary Wroth. While a scholar's institution is often viewed as an index of their status in the profession, such elitism has always been myopic and is all the more so today given the dismal state of the academic job market. Along similar lines, several contributors to this special issue observe that a field's significance should not be inferred from its visibility (or lack thereof) at elite universities, especially when the field in question seeks to redress structural biases (e.g., African American literature). To take a more systemic view, we need only follow the money. The lack of 
female "postholders from top-ranking universities" in the collections critiqued by Purkiss actually results from institutional hiring priorities that conflate cultural capital and financial capital. The perennial need to employ Shakespearean scholars who can teach high-enrolling courses on Shakespeare is an obvious example of this tendency. Yet while Shakespeare occupies an essential place in the canon and most curricula, "there is nothing inevitable about Shakespeare" and any early modernist can teach his works, as Erin McCarthy contends in this special issue. Administrative decisions thus make it more difficult for women academics to mentor the next generation of scholars and in turn to build a critical mass of researchers who study early modern women's writing. While the marginalization of early modern women writers may seem to be a self-perpetuating problem, it has resulted in large part from economic factors. To remedy this situation, we must do the hard work of turning from the realm of surface effects to the hidden causes that lurk below. We must also search for creative solutions that can counteract the effects of these structural issues, as returning to the example of Margaret Hannay demonstrates. Because she did not teach graduate students, Hannay made a point of mentoring graduate students and junior faculty in order to advance and expand the field.

In the wake of Purkiss's review, it is time for our field to take stock of its current state and consider its future. This special issue brings together fifteen articles that engage in a full and frank discussion of the many issues raised by Purkiss. Rather than engaging in an ad feminam attack on Purkiss or her work, these essays participate in a scholarly conversation that began long before the publication of her review. We asked contributors to consider a series of questions at the heart of that ongoing dialog:

- Should we continue previous efforts to integrate women writers into the mainstream canon? If so, how might we go about it? If not, why not?

- To what extent should we attempt to place women writers in conversation with canonical and/or male authors like Milton, Shakespeare, and Spenser? What are the benefits and/or drawbacks of studying women's texts in isolation or in relation to male-authored works?

- Is it time for us to move beyond the field's defining concepts-female identity and female agency? What fresh insights might be generated by turning to new models of identity, such as intersectionality? Or should we eschew identity politics altogether? 
- How might the field continue to develop and/or incorporate critical theory, such as critical race theory, feminist formalism, queer theory, etc.?

- In what ways can digital humanities lead to breakthroughs in the study of early modern women writers?

- How can we revitalize our teaching of early modern women writers? What new directions might we take in the classroom?

In order to best represent this conversation, we adopted a new format for Criticism: a forum of short articles that engage in meta-commentary on the field, a development that is in line with the journal's mission to foster "theoretical and critical debate as well as formal and methodological self-reflexivity and experimentation." ${ }^{14}$ Believing that a robust debate would result from a diversity of perspectives, we sought out contributors from across the globe who were at different career stages and who held tenure-stream as well as non-tenure-track positions. We also prioritized the inclusion of scholars of color. The resulting essays are provocative and speculative, ranging from rigorous personal reflections to tightly argued case studies of particular authors or texts.

We have divided this special issue into four sections. The five essays included in the first section, "Manifestos," consider the history of the study of early modern women's writing and offer compelling visions of its future. These essays, despite their disagreements, share a belief that we need to reconsider the frameworks that have hitherto guided the study of early modern women's writing. In the first essay, "Loss and Longevity: Rhetorics and Tactics of Early Modern Women's Writing," Marie-Louise Coolahan reflects upon one such foundational model: the recovery of a lost tradition of women's writing. This Woolfian paradigm has impelled numerous researchers into archives and rare book rooms to recover writing by women. But it has also had a less welcome consequence, encouraging researchers to view themselves as feminist saviors while ignoring other reasons for the exclusion of women writers from the canon. These reasons include changes in aesthetic categories, shifting models of historiography, and evolving understandings of generic value, as well as patriarchal oppression. Coolahan then reminds us of how much the study of early modern women writers has achieved besides establishing a countercanon of women's writing. Because of its interdisciplinarity, she notes, it has improved our understanding of early modern print and manuscript culture, religious history, and material culture in general. But these advances, Coolahan warns, can easily be erased without "perpetual 
policing." She urges tenured scholars, teachers, researchers, and editors to utilize their hard-won power by promoting the work of women writers within their curricula and classrooms, while at the same time "modeling... an open, inclusive criticism" in their own scholarship by analyzing women writers alongside their male contemporaries. Coolahan concludes by encouraging scholars of early modern women's writing to actively seek new venues for their scholarship, including the so-called "GLAM" sector (Galleries, Libraries, Archives, and Museums).

Erin McCarthy begins the next essay ("Is There Room for Judith Shakespeare and Her Brother, Too?") with a reflection upon her own experience in an American doctoral program in the first decade of the twentieth century. She observes that while no one explicitly told her not to write a dissertation on women writers, there was a general perception that if she wanted to get a job, she needed to write on canonical (male) writers and that producing a dissertation on women's literature might "(further) limit [her] options." It was only much later, after she published an article on Aemilia Lanyer and began working on the RECIRC project (The Reception and Circulation of Early Modern Women's Writing) helmed by Coolahan, that she started to consider herself a scholar of early modern women's writing. McCarthy concludes that her experience attests to a larger, structural issue: Shakespeare's role as the center of the field. "What room," she asks, "is there for women's writing in his orbit?" Drawing upon her experience with quantitative analysis, McCarthy used the MLA International Bibliography to compare the proportion of scholarly works written on Shakespeare with those written on early modern women writers since 2010. The results are eye-opening: " $49.39 \%$ of all works addressing the sixteenth or seventeenth centuries ... have discussed William Shakespeare and his works; the top ten is rounded out with nine more familiar male names." The results of McCarthy's detailed study are graphically represented in a tree map that shows at a glance the prominence of Shakespeare within scholarship on the early modern period. Her analysis suggests that the "discipline sends aspiring early modernists not-so-subtle cues that women writers are less important and less worthy of study and that this lesser status could, in turn, limit already scarce job prospects." McCarthy concludes by urging those of us with secure employment to think actively about what we choose to teach and research, and to increase our efforts to diversify our curriculum. She also encourages us to reconsider our hiring practices: do we really need, she asks, a Shakespeare expert to teach an introductory course on Shakespeare? Like several of the contributors to this special edition, she also reminds us that we must continue to work on integrating women's 
writing into the scholarly mainstream. McCarthy concludes by asking scholars of women's writing to reflect on "why we do this work at all," posing two vital queries: "Whose stories do we privilege, and who are they meant to serve?"

The remaining pieces in this section engage with these questions of privilege and audience by analyzing the intersection of gender and race in early modern scholarship. In "How Race Might Help Us Find 'Lost' Women's Writing," Joyce MacDonald offers a sharp critique of the class, race, and gender ideologies that contribute to the denigration of early modern women's writing-and of the scholars who study it. Like Coolahan, MacDonald questions the political usefulness of the rhetoric of loss. Noting that the attorney general of Kentucky condemned the tragic "loss" of Breonna Taylor's life while refusing to hold anyone responsible for her death, MacDonald powerfully demonstrates how a focus on loss can be deployed to obscure structural oppression. "To call something-or someone- 'lost," MacDonald observes, "is to obfuscate responsibility for the disappearance, to ignore what else may have had to be erased or forgotten in order to facilitate it, and perhaps even to lay the groundwork for justifying the erasure." Women's writing was lost, MacDonald insists, not because absent-minded academic uncles turned their attention elsewhere, but because patriarchy has structured and continues to structure academic institutions and scholarship. Responding to Purkiss's remarks concerning the timidity of female scholars, MacDonald foregrounds the structural inequalities that shape their reticence. Female scholars teach a curriculum in which they are not adequately represented and work in institutions where men occupy a majority of administrative positions. Precarity and the consequent need for solidarity, MacDonald writes, can make it difficult for women scholars to openly disagree with their feminist colleagues. MacDonald concludes by suggesting that scholars of early modern women's writing might learn from the example of Carter Woodson, who helped found the discipline of Black Studies while working outside academia. Might the study of early modern women writers be advanced, she wonders, if we stopped working for the inclusion of women writers within the literary canon and instead embraced "a strategic feminist separatism" that articulated its own standards of value and judgment?

In the fourth essay, “'Undisciplined': Early Modern Women's Writing and the Urgency of Scholarly Activism," Kimberly Coles explores a concern shared by many of the contributors to this special edition, as well as its editors: how can we, as scholars of early modern women's writing, better explore the intersecting genealogies of race and gender? We have failed to do so thus far, Coles insists, and the "blame falls entirely on us." The field 
has not yet recognized that "race in the early modern period is a concept at the intersection of a set of concerns: lineage, religion, sexuality, custom, and nation" and that, crucially, "these categories often serve as support or solvent to the terms by which the category of 'woman' is understood." Why have we neglected to adopt this intersectionalist approach? Coles argues that we, as scholars of early modern women's writing, have been too invested in affirming the virtue of our literary foremothers. We have searched the archive in order to discover subversive opponents of patriarchy, women who could serve as role models for our own contemporary struggle. We must reject this model and commit ourselves more fully to "ugly history," in Coles's words; that is, to a model of historical inquiry that acknowledges the extent of white women's participation in the establishment and maintenance of racial categories. We must acknowledge how white women writers, as "principal domestic actors," were complicit in the production of racial hierarchies as they sought to negotiate their own authority. Coles identifies three discourses through which early modern white women affirmed racial hierarchies: receipt collections, conduct manuals, and nondramatic literature. These areas, she suggests, are ripe for further research. Coles further observes that recent bioarchaeological research on burials in late medieval and early modern England has revealed a surprisingly diverse population; she acknowledges that this research has yet to be fully evaluated, but concludes that "if one third of the population in London was not of European descent, the absence of a diverse English population in literature, as opposed to archival documents, is a deliberate omission, not an accident." In drawing our attention to these gaps, Coles identifies several tantalizing directions that scholars could and should pursue as we begin to grapple with early modern women writers' roles in producing contemporary discourses of race.

Finally, Melissa Sanchez begins "What Were Women Writers?" by questioning the usefulness of "women writers" as a descriptive category. Taking a monograph by Kenneth Warren as her starting point (What Was African American Literature?, 2012), she argues that just as Warren (controversially) concluded that the value of the descriptive category of African American Literature had "eroded" in favor of "diasporic and global" understandings of racial identity, so the usefulness of the category of "woman writers" has faded. But rather than eliminating the category entirely, Sanchez advises, we need to understand it more expansively. We need to stop valorizing early modern women writers as brave opponents of patriarchy and pay more attention to how sixteenth-and seventeenth-century women used their writings to support the colonialist oppression of indigenous peoples. Like the other critics 
included in this section, Sanchez exhorts scholars of early modern women's writing to stop trying to please the white male patriarchs who guard the literary canon. We need to find new audiences for our work, and we can discover them in those students and activists who have historically rejected the study of early modern women's writing as too conservative, too white, and too imbricated in colonialist and capitalist structures of power. This requires not that we turn our attention away from early modern women writers, Sanchez insists, but that we study them more closely, "placing women's writing at the center of early racial discourses and colonial projects, which have been understood as promoting enslavement, genocide, and human-made climate change." One way in which we might accomplish this, Sanchez concludes, is by drawing upon contemporary artists and writers who practice what Saidiya Hartman has called "critical fabulation," imaginatively inserting representations of women and other oppressed peoples into the historical and literary record.

The next section, “Theories, Methods, and Cases," explores specific writings of early modern women (and men) through the lenses of contemporary theories. By emphasizing the intellectual depth and complexity of early modern women's writing, these four essays serve as a subtle rejoinder to those who contend that women's writing is unsuitable for inclusion within the canon. In "Reading Milton Like a Woman," Sarah Kunjummen "flips the script," suggesting that we might use approaches developed within the field of early modern women's writing to study canonical male authors. Like Coolahan, Kunjummen observes that the interdisciplinarity of early modern women's writing places it at the cutting edge of theoretical developments within the fields of literature, history, and religion. By embracing these developments and building upon them, early modern women's writing has thus historically provided an impetus for growth in early modern studies. What might happen, she wonders, if we were to now "turn back to the broader field of early modern culture with eyes trained by the study of women specifically"? Kunjummen's essay tests this approach by juxtaposing the writings of Lucy Hutchinson, Margaret Cavendish, and John Milton. Kunjummen wryly observes that while scholars frequently explore how the writings of Hutchinson and Cavendish were influenced by their husbands, "Milton's most-examined collaborator is still the Holy Ghost." By insightfully reading key moments in Paradise Lost in relation to Milton's familial and domestic milieu, Kunjummen demonstrates how methodologies developed within the field of early modern women's writing might illuminate the writings of canonical male authors. 
In "Reading Marguerite de Navarre: An Aged Professor's Meditation," Anne Lake Prescott explores the relevance of ecocriticism to early modern women's writing through a case study of Marguerite de Navarre, the author of the Heptameron and Miroir de l'ame pécheresse (The Mirror of the Sinful Soul) as well as the sister of the French king François ${ }^{\mathrm{er}}{ }^{\text {. As an }}$ accomplished and elite female author who wrote in recognizably literary genres and whose Miroir was translated into English by Elizabeth I, Marguerite has received quite a bit of critical and scholarly attention. Prescott argues that we can learn something new about her writings by examining them through the lens of ecocriticism, which raises "the deep and difficult question of how we relate our fictions, criticism, and scholarship to the natural world." Prescott analyzes Marguerite's representation of pigs in the Heptameron, whose juxtaposition of pigs and monks has traditionally been understood as a satire of monasticism. But, Prescott asks, does Marguerite know anything about "real” pigs? Might a deeper understanding of pigs improve our understanding of Marguerite's literary fiction? Prescott recognizes that this approach may lead to avenues that Marguerite herself never imagined, but she insists that the use of nature is never natural. More crucially, Prescott observes that we value Marguerite's representations more when we ourselves know more about actual pigs. This witty reflection contends that increased appreciation should be one of the goals of teaching and scholarship. All critical theories, whether modern or postmodern, that encourage such appreciation should be welcomed.

In "Race Thinking in Margaret Cavendish's Drama," Sujata Iyengar considers how a focus upon race and intersectionality might improve our understanding of early modern women writers. Central to her analysis is a 1944 essay by Hannah Arendt, which locates the emergence of what Arendt terms "race-thinking" within eighteenth-century liberal individualism. Iyengar uses Arendt to explore the interrelation of gender, rank, and skin color in Margaret Cavendish's two-part play Love's Adventures (1662) as well as a later play, The Bridals (1668). Through a careful reading of individual scenes, Iyengar examines how "the intersectional hierarchies of rank, skin color, gender and sexual autonomy thus triumph over an imagined innate or even a 'cultivated' merit or virtue" within Cavendish's drama. For the aristocratic Cavendish, then, an illusory meritocracy benefits only a select few who are already considered worthy because of their privileged status. For Cavendish, Iyengar concludes, "class, gender, and lack of cultivation combine to become a kind of caste: the power-driven labor-, appearance-, and education-dependent hierarchy we call race." Like Prescott, Iyengar demonstrates how contemporary theory can reveal 
new insights into early modern women writers and make these works more compelling to contemporary readers. While the study of early modern women writers has often and understandably emphasized historicism, these essays reveal the value of taking a more presentist approach.

In "Between Women: Archival and Theoretical Methods in Early Modern Women's Writing," Christopher Shirley indicates that methodological innovations bridging the perceived gap between historicism and presentism can illuminate the place of men within the study of early modern women's writing. Tracing the historically complex relationship between the study of early modern women's writing and queer theory, he demonstrates that a combination of historical and theoretical approaches, grounded upon a materialist textuality, may reveal new and compelling insights into early modern women's textual productions. Considering two poems by Katherine Philips ("To My Dearest Antenor on His Parting” and "To My Excellent Lucasia, on Our Friendship"), Shirley shows that while these works may represent homosocial and heterosocial bonds differently, textual analysis suggests that Philips and the "other women in her coterie articulated female-female desire through textual exchanges with men." In the Rosania manuscript, which is one of the most reliable sources for Philips's poems, a letter by "Polexander," a male member of Philips's coterie, prefaces the collection and "textually triangulates the affective bonds between" Philips and her female dedicatee. Heterosocial relationships, in other words, could be used to reinforce and support female homosocial bonds. Shirley's essay thus provocatively demonstrates the insights that can be gained when we consider texts produced by men as part of the corpus of early modern women's writings.

Our next section, "From the Archive to the Classroom," contains four essays that analyze editorial and pedagogical practices in order to explore the impact of early modern women's writing upon our understanding of the canon. In "Hidden in Plain Sight: Editing and (Not) Canonizing Early Modern Women's Writing," Paul Salzman considers how the recovery of early modern women writers has galvanized our understanding of the importance of editing. He observes that the texts of early modern women writers are increasingly being published in authoritative editions, a strong indicator of canonicity and once the sole prerogative of male authors. Just as importantly, Salzman remarks that scholars of early modern women's writing have produced a sizeable number of teaching editions, which often include interpretive and research frameworks for students and have greatly increased the visibility of women within the undergraduate curriculum. He also notes the value of online editions of early modern writers, such as The Pulter Project and Margaret Cavendish's Poems and Fancies, 
that provide easy access for students and scholars, although he cautions that we could do more to consider how changes in technology might render these online editions obsolete. In contrast to Purkiss's claim that women's writing has had little impact upon the larger field, Salzman argues that these editions have been foundational to the development of early modern studies since they have helped establish women writers within the larger canon and encouraged scholars to apply more contemporary theories, especially involving race and sexuality, to these works.

Steven May's “The Renaissance Women's Canon, Past, Present, and Future," provides a case study of a poem by Lady Mary Cheke in order to discuss the relationship between manuscript circulation, gender, and canonicity. May notes that in the 1970s, there were multiple female scholars working in the field of early modern literature but few known early modern women writers; surveying the field today, he observes, "We've come a long way." But there is still work to be done. We need more authoritative editions of women writers; we also need more biographical information about these women. Some of this information, May observes, could be mined from letters. We also need to know more about women's possible participation in scribal networks, since this might enable us to recover additional works by women. May observes that although he discovered Cheke's poem nearly thirty years ago, we still don't have an authoritative edition of it, in part because it exists in multiple manuscripts. Nor do we know a great deal concerning the author's life. May concludes with a caution: even if we were to establish a comprehensive canon of early modern women writers, we would still have to ask ourselves difficult questions about which genres of early modern women's writing we choose to teach, since his experience teaching undergraduates for nearly thirty-five years suggests that many students have a difficult time connecting with works by early modern women, especially religious works.

May's remarks underscore the close connection between editorial work and teaching, a topic that is also foregrounded in the final two essays of this section. In "Unconventional Experiments: Teaching Early Modern Women Writers," Victoria Burke observes that when she first began to teach women writers, she would begin by asking the students to read excerpts from A Room of One's Own. She would then spend much of the first class showing the students examples of early modern women's writing to demonstrate how wrong many of Woolf's claims about early modern women writers were. It was enjoyable, Burke observes, to share the fruits of decades of archival work, to provide students with evidence of a tradition of women's writing. But Burke's teaching has now changed, in large part because of two theoretical developments. First, the emergence of 
book history effected a sea change in our understanding of early modern women's writing, Burke observes, by showing that print was not necessarily the only, or even the most common, means of circulating poetry. Many early modern writers, both male and female, chose to share their works via manuscript; when students realize this, their perception of women's writing, and its place in the canon, changes. Like Salzman, Burke observes that this material turn has been further encouraged by the emergence of superb online editions that allow students to compare manuscript versions of poems so that they can see for themselves the relation between orthography and authorial intent. The second development is a renewed formalist attention to literary value and aesthetics, an attention facilitated by the emergence of high-quality digital editions. Burke concludes that these superb digital projects enable students to consider early modern women writers as skilled artists, who carefully crafted their literary compositions.

In “Teaching Women Writers in a 'Great Books' Program,” Micheline White reflects upon her experience teaching early modern women writers for the past twenty years in a Great Books program at a Canadian university. She observes that while women writers have long been well integrated into the curriculum at her institution, two material developments have transformed her pedagogy. First, like Salzman and May, she emphasizes the importance of the emergence of high-quality teaching editions. When White first began teaching, she relied upon microfilm printouts of female authors such as Ann Dowriche and Katherine Parr. This was problematic because students found the black-letter font and lack of annotation or critical guidance difficult. White observes that while students enjoyed reading these works, and spent considerable time debating whether they were "great," few chose to write research papers on them. This changed with the emergence of high-quality teaching editions. Students are now better able to understand these works within their literary and historical contexts, and more students opt to pursue the research paths sketched out by the editors. The second development that White discusses is her institution's decision to embrace a learning management system (LMS) that delivers links or PDFs of texts to student laptops. This development has undeniably transformed how students see early modern women writers: White observes that the digitized writings of Katherine Parr look little different from those of Luther or Cranmer on a student laptop. But such homogenizations bring their own challenges. Her students are now less attuned to the impact of patriarchy, less able to grasp the material factors that both enabled and restricted Parr's textual productions. As a result, White now spends more time emphasizing the social, political, economic, 
and gender factors that made it difficult for women to participate in literary culture. Emphasizing how race intersected with gender, White concludes, like so many of the contributors to this special issue, that we have still not done enough to integrate diverse authors within the study of early modern women writers.

The final section, "Utopian Vistas," contains two essays that offer panoramic views of the field in order to explore its achievements, failings, and potential. The title of Patricia Demers's essay, "The Presence of the Now," derives from an aphorism by Walter Benjamin: history is "time filled with the presence of the now." For Demers, this aphorism gestures toward a complex dynamic of "visibility, audibility, and empathy" that informs much scholarship on early modern women's writing. Demers begins by considering Hecatodistichon (1550) as a test case for analyzing the workings of this dynamic. While an earlier generation of scholars was eager to ascribe authorship of this Latin panegyric on Marguerite de Navarre to the young Seymour sisters (aged twelve, ten, and nine years old), recent work has suggested that the poem, a compilation of other lyrics, was actually the work of their "wizard-tutor." Both of these attributions, Demers suggests, are misguided. She urges that we adopt a more nuanced understanding of the poem's authorship that resists treating the girls as "ventriloquized puppets" even as it places the poem within a larger, international literary culture in which "quotation and misquotation" were an integral aspect of literary production. Demers recognizes that her interpretation will please neither those scholars who are interested in discovering a lost tradition of female authorship nor those who unconsciously seek to confirm their own pessimistic assessments of early modern women's capacity for literary creation, but she insists that it offers a more accurate picture of women's participation in early modern culture. Demers brings a similarly nuanced approach to the present moment and the potential of scholarship on early modern women. She recognizes that "brave new digital frontiers" can foreground women's participation in wider intellectual and cultural movements by unearthing previously hidden women writers, but at the same time she cautions that "big data" can obscure women's numerically limited participation within print culture. Perhaps drawing upon her experience as an administrator as well as a scholar, Demers concludes by considering the university as a platform for the dissemination of knowledge. She observes that one of the easiest ways for scholars to ensure the continued visibility of women writers is through teaching collaborations within our own departments but also (and perhaps more crucially) across the larger university. 
Sarah C. E. Ross begins the final essay in this special issue, "A Small Room with Large Windows: Early Modern Women's Writing in 2020,” by considering Woolf's portrayal of the woman writer in "a room of [her] own." While this paradigm might resonate with twentieth- and twentyfirst-century female readers, Ross observes, it does not accurately reflect the experience of early modern women writers. The image of a room of one's own suggests quietism, isolationism, and privacy, yet early modern women were active participants in the literary, political, and religious cultures of their time. As a result, we need a new metaphor. Ross finds one in the poetry of Allen Curnow, a Pākehā (white European) settler of New Zealand who was "obsessively interested in what the literatures and cultures of the English past may mean to an imagination relocated." Scholars of early modern women's writing might usefully consider themselves as occupying what Curnow describes in his poetry as "a small room with large windows." Such an image more accurately reflects the way in which the study of early modern women's writing has shifted "single and exclusionary historical narratives" and so encouraged scholars "to come at our cultural histories from different angles, to 'recognize / The whole three hundred and sixty degrees,", as Curnow puts it. Drawing upon her experience as a scholar, editor, and teacher, Ross offers a largely positive assessment of the field. Like other contributors, Ross suggests that the interdisciplinarity of scholarship on early modern women's writing has enriched the field of early modern literature as a whole. She also observes that many of the most recently published and critically acclaimed books on the early modern period employ an "integrated approach" to the study of genre, which intentionally includes both male and female writers. At the same time, Ross recognizes that the field needs to keep expanding its horizon. In particular, she urges us to do more to consider those vistas ignored by scholars of early modern women writers, "most urgently, the intersections with race, indigeneity, and colonization."

Taken together, these essays suggest that there is no one future for scholarship on early modern women writers, but rather a variety of paths that converge and diverge in exciting and interesting ways. Scholars will continue to locate and edit the works of women writers, bringing these texts into the canon and the classroom. They will also continue to consider how our current understanding of the literary derives from Romantic ideas about aesthetic value and to interrogate how this understanding implicitly devalues many female-authored compositions, especially those in religious genres. Analysis of these neglected forms of writing may even generate new critical approaches that can enrich and 
redirect the scholarly conversation at large, as it has with feminist formalism. For example, critics have long read Shakespeare through the lens of philosophy, arguing that his works transcend historical context to illuminate the human condition. Women writers have not received similar treatment, perhaps because of the default assumption that their texts appeal to only a narrow audience and are thus less representative of humanity in general. We sorely need a feminist philosophical approach to early modern women's writing, in which scholars do not write about female authors but rather think with them about the great existential questions that have vexed generations of human beings. ${ }^{15}$ At the same time, the study of early modern women's writing has long embraced interdisciplinarity, and the field will continue to push the boundaries of early modern literature through research methodologies that decenter aristocracy, heterosexuality, masculinity, and whiteness in favor of more diverse understandings of class, gender, race, and sexuality.

Perhaps most importantly of all, these essays suggest that it is time to rethink the fundamental premise of this subfield: that we must integrate early modern women writers into the canon. As Danielle Clarke observed nearly two decades ago in relation to editions of women's writings, "The aspiration to enter the canon has been something of a canard for these texts." ${ }^{16}$ The opening of Purkiss's review serves as a salutary reminder that this "aspiration" informed the labors of the first generation of scholars in this field: "Some of us set out to reverse the work of time, because we found that it mattered to us. What we expected to happen was that the Western canon would be revised to include our new discoveries." By those criteria, the feminist project has failed, as a glance at the Norton or any similar anthology reveals. Yet this special issue reveals that the true failure lay not in the work of feminist scholars but rather in the perception that incorporating women into the canon would remedy larger patriarchal injustices.

As we move into a twenty-first century defined by social justice movements such as Black Lives Matter and \#MeToo, we must begin to think outside of traditional literary paradigms. The canon, like so many other structures and systems of oppression, is under great pressure as the discipline of English_-and the humanities in generalstares into the void of an existential crisis that threatens to marginalize it in favor of STEM and more ostensibly career-oriented subjects. At the same time, our students demand curricula that are more representative of their diverse identities and experiences, causing the canon of dead, white men to appear more and more like a shibboleth that should be abandoned. The anti-hierarchical, idiosyncratic corpus of 
early modern women writers offers a glimpse of a more egalitarian model for literary study as it could be, when the center finally gives way. Scholars of early modern women's writing have been, and will continue to be, instrumental in creating this vision. To return to the Prufrockian metaphor, early modern women writers are not, and never were, ladies in waiting. Rather, the study of their texts has been an engine of incremental change that is slowly shifting the frame of early modern literature itself away from canonicity and toward "sparkling multiplicity." The future of early modern women writers is thus the future of early modern literature itself.

Jaime Goodrich is Associate Professor of English at Wayne State University and the editor of Criticism. She has published widely on the educations, lives, and religious writings of early modern women, especially Benedictine and Franciscan nuns.

Paula McQuade is Professor of English at DePaul University in Chicago. Her research interests center on early modern Protestant women writers, with a particular interest in domestic religious practices.

\section{NOTES}

1. On the experience of teaching early modern women writers in the twenty-first century, see Mihoko Suzuki, “Studying Early Modern Women Writers in 2018," Sixteenth Century Journal 50, no. 1 (2019): 111-17.

2. Margaret J. M. Ezell, "Invisibility Optics: Aphra Behn, Esther Inglis and the Fortunes of Women's Works," in A History of Early Modern Women's Writing, ed. Patricia Phillippy (Cambridge: Cambridge University Press, 2018), 45.

3. https:/link.springer.com/referencework/10.1007/978-3-030-01537-4, accessed December 8,2020 .

4. For a related discussion about the scholarly future of feminism in early modern literature, see Ania Loomba and Melissa E. Sanchez, ed., Rethinking Feminism in Early Modern Studies: Gender, Race, and Sexuality (New York: Routledge, 2016).

5. Patricia Phillippy, “Introduction: Sparkling Multiplicity,” in Phillippy, History of Early Modern Women's Writing, 2.

6. Lara Dodds and Michelle M. Dowd, "Happy Accidents: Critical Belatedness, Feminist Formalism, and Early Modern Women's Writing," Criticism 62, no. 2 (2020): 169.

7. Ramona Wray, "Anthologising the Early Modern Female Voice," in The Renaissance Text: Theory, Editing, Textuality, ed. Andrew Murphy (Manchester, UK: Manchester University Press, 2000), 55-72.

8. Danielle Clarke, "Nostalgia, Anachronism, and the Editing of Early Modern Women's Texts," Text 15 (2003): 187-209.

9. Nigel Smith, “The Rod and the Canon,” Women's Writing 14, no. 2 (2007): 232-45. 
10. Alice Eardley, "Recreating the Canon: Women Writers and Anthologies of Early Modern Verse," Women's Writing 14, no. 2 (2007): 270-89; Sasha Roberts, “Women's Literary Capital in Early Modern England: Formal Composition and Rhetorical Display in Manuscript and Print," Women's Writing 14, no. 2 (2007): 246-69.

11. Dodds and Dowd, "Happy Accidents," 173-75; Phillippy, "Introduction," 4-6.

12. Diane Purkiss, "Rooms of All Our Own," Times Literary Supplement 6046 (Feb. 2019).

13. Diana E. Henderson, "Tempestuous Transitions and Double Vision: From Early to Late Modern Gendered Performances in Higher Education," in Loomba and Sanchez, Rethinking Feminism, 68.

14. https://digitalcommons.wayne.edu/criticism/, accessed November 24, 2020.

15. On the need for a turn to feminist philosophy that reads authors beyond Shakespeare in philosophical terms, see Jaime Goodrich, Writing Habits: Historicism, Philosophy, and English Benedictine Nuns, 1600-1800 (Tuscaloosa, AL: University of Alabama Press, forthcoming 2021).

16. Clarke, "Nostalgia," 188, emphasis in the original. 